Editor's Note: These short reviews of recent JNeurosci articles, written exclusively by students or postdoctoral fellows, summarize the important findings of the paper and provide additional insight and commentary. If the authors of the highlighted article have written a response to the Journal Club, the response can be found by viewing the Journal Club at www.jneurosci.org. For more information on the format, review process, and purpose of Journal Club articles, please see http://jneurosci.org/content/ preparing-manuscript\#journalclub.

\title{
Seeking an In Vivo Neuronal Context for the PINK1/Parkin Pathway
}

\author{
(D) Nicholas R. Ader ${ }^{1,2}$ \\ ${ }^{1}$ Division of Cell Biology, Medical Research Council Laboratory of Molecular Biology, Cambridge CB2 0QH, United Kingdom and ${ }^{2}$ Biochemistry Section, \\ Surgical Neurology Branch, National Institute of Neurological Disorders and Stroke, National Institutes of Health, Bethesda, Maryland 20892 \\ Review of Sung et al.
}

Despite the passage of nearly two centuries since James Parkinson penned his seminal work, "An Essay on the Shaking Palsy," the neurobiology of the disease that now shares his name remains unclear (Parkinson, 2002). Although the majority of Parkinson's disease (PD) cases are idiopathic, advances in sequencing technology at the turn of the century allowed for the identification of five genes mutated in familial PD. These include PARK2, which encodes the E3 ubiquitin ligase Parkin, and PARK6, which encodes phosphatase and tensin homolog-induced kinase 1 (PINK1) (Kitada et al., 1998; Valente et al., 2004). In the last two decades, researchers have sought to understand the role of these proteins in normal neuronal systems and PD pathogenesis.

Investigations into the function of PINK1 and Parkin have revealed a complex signaling pathway for targeted removal of damaged mitochondria through autophagy machinery, or mitophagy (Nguyen et al., 2016). However, much of the investi-

Received Aug. 9, 2016; revised Sept. 14, 2016; accepted Sept. 19, 2016.

I thank Tasneem Maner, Stefano Giandomenico, and Madeline Lancaster for constructive conversations during manuscript drafting; and Richard Youle and Wanda Kukulski for helpful comments on drafts of this work.

The authors declare no competing financial interests.

Correspondence should be addressed to Nicholas R. Ader, MRC Laboratory of Molecular Biology, Francis Crick Avenue, Cambridge Biomedical Campus, Cambridge CB2 OQH, United Kingdom. E-mail: nader@mrc-Imb.cam.ac.uk.

DOI:10.1523/JNEUROSCI.2525-16.2016

Copyright $\odot 2016$ the authors $\quad 0270-6474 / 16 / 3611165-03 \$ 15.00 / 0$ gation into PINK1/Parkin activity has been performed in non-neuronal cells. Because PD is fundamentally a disease affecting neurons in the substantia nigra pars compacta, understanding PINK1/ Parkin activity in neurons is a current challenge in the field.

A large body of in vitro data suggests that PINK1 and Parkin mutations heavily disrupt mitochondrial dynamics. Mitochondria form a complex and dynamic network throughout the cell. This network is carefully maintained through a balance of fission and fusion events (van der Bliek et al., 2013). The mitochondrial network is able to shift the balance between fragmented (more fission, less fusion) and filamentous (more fusion, less fission) in response to the needs of the cell (Youle and van der Bliek, 2012). To respond to stress conditions, the E3 ubiquitin ligase activity of Parkin is activated by PINK1 and targets a plethora of mitochondria-associated proteins (Pickrell and Youle, 2015). Activation of the PINK1/Parkin pathway leads to an increase in mitochondrial fragmentation, thought to be caused by the targeted degradation of key mitochondrial fusion proteins (mitofusins), the large GTPases Mfn1 and Mfn2 (Tanaka et al., 2010).

Previous work in cultured neurons suggested that PINK1 and Parkin primarily regulate the last stage of mitochondrial lifespan, namely, mitophagy. Although
PINK1/Parkin-mediated mitophagy was shown to occur in axons of cultured neurons (Ashrafi et al., 2014; Bingol et al., 2014), there is still debate about whether these mechanisms take place in neurons in vivo. In Drosophila, Devireddy et al. (2015) presented evidence to argue that, unlike in in vitro systems, mitophagy does not occur in the axons in vivo: loss of PINK1 did not lead to axonal accumulation of mitochondria or drastic changes in mitochondrial morphology. To extend this work, Sung et al. (2016) characterized motor neurons lacking Parkin using GFP targeted to the mitochondria (mito-GFP) in the intact nervous system of dissected Drosophila larvae, a preparation accepted to replicate in vivo conditions. They report three major findings: (1) loss of Parkin resulted in a lower mitochondrial density in motor neuron axons and neuromuscular junctions; (2) changes in mitochondrial morphology resulting from Parkin loss were limited to the neuronal cell body; and (3) Parkin-dependent mitophagy was absent in axons.

Because previous literature suggested that Parkin is responsible for both mitochondrial quality control and trafficking of axonal mitochondria (Wang et al., 2011; Liu et al., 2012b; Saxton and Hollenbeck, 2012), the authors speculated that, if these two functions are related, loss of Parkin could lead to a buildup of defunct mitochondria in the axon, unable to be 
transported back to the cell body. Instead, they found that mitochondrial trafficking was reduced in both anterograde and retrograde directions, but mitochondrial motility characteristics were unchanged in Parkin-null neurons (Sung et al., 2016, their Fig. 1; their Table 2). After analyzing mitochondria density, the authors deduced that the reduction of mitochondrial transport in motor neuron axons was due to an overall decrease in mitochondria density in both larval motor neuron axons and sensory axons of adult flies (Sung et al., 2016, their Fig. 2).

The authors characterized the Parkinnull phenotype further by examining the smaller mitochondria population present in the axon in greater depth. They assessed mitochondria health by measuring mitochondrial membrane depolarization and mitochondria length, which they hypothesized would increase due to Parkin-mediated degradation of mitofusins (Deng et al., 2008; Poole et al., 2010; Ziviani et al., 2010). The authors were surprised to find that these markers of mitochondria health did not indicate the presence of defunct mitochondria in their system (Sung et al., 2016, their Fig. 4). In contrast, Sung et al. (2016) found that neurons cultured in vitro did display both of these markers for dysfunctional mitochondria (their Fig. 9), which they argue provided evidence for an alternate role for Parkin in neurons in vivo.

As most mitochondrial biogenesis is thought to occur in the cell body, with mitochondria then transported distally (Davis and Clayton, 1996), the authors speculated that lower levels of axonal mitochondria in Parkin-null Drosophila could result from mitochondrial dysfunction in the soma. Sung et al. (2016) found that the cell bodies of neurons lacking Parkin contained mitochondrial networks with higher degrees of connectivity, presumably as a result of some combination of fission inhibition and fusion promotion (their Fig. 5). Without fission, no new mitochondria can be produced. Thus, the authors speculated that either a lack of mitochondria biogenesis or an inability to transport interconnected mitochondria explained the low levels of axonal mitochondria.

Sung et al. (2016) next examined Parkin-dependent mitophagy. In addition to mito-GFP, the authors tagged autophagy-related protein 8 (Atg8), a marker for autophagy-associated membranes, with red fluorescent protein and looked for areas of colocalization in both the cell bodies and axons of Drosophila neurons. They compared wild-type and Parkin-null neurons, as well as neurons in larvae grown in basal and starvation conditions (Sung et al., 2016, their Fig. 6). Surprisingly, the authors did not detect the expected colocalization events representative of mitophagy in either wild-type or Parkin-null flies under any conditions. Importantly, while starvation induces a form of nonspecific autophagy called macroautophagy (Gomes et al., 2011; Rambold et al., 2011; Ghosh et al., 2012), Parkin-dependent mitophagy is thought to not be induced under starvation conditions (Chen et al., 2010; Wang and Klionsky, 2011). To selectively increase Parkin-mediated mitophagy in vivo, the authors could attempt to mutate the mitochondrial DNA polymerize $\gamma$ (Trifunovic et al., 2004; Kujoth et al., 2005; Vermulst et al., 2008) or incubate in an oxygen-deficient environment (Liu et al., 2012a).

Although our knowledge of PINK1/ Parkin function in non-neuronal cells has been greatly expanded in the last two decades, the role of these proteins in neurons in vivo is still poorly understood. Expanding on neuronal work in vitro, Sung et al. (2016) provide more insight into the effects of Parkin loss in larval Drosophila neurons by demonstrating that, rather than accumulate dysfunctional mitochondria, axons have less mitochondria overall. Although Parkin was thought to maintain the mitochondrial population through axonal quality control, their results questioned this role for Parkin in vivo and shifted the authors' focus to the soma. There, the authors observed that Parkinnull flies appear to have an overly connected mitochondrial network, suggesting that Parkin may serve to facilitate mitochondria biogenesis in the soma and/or transport to the axon.

As an E3 ubiquitin ligase, Parkin is thought to promote fission in vitro through ubiquitin-mediated degradation of mitofusins (Tanaka et al., 2010). Further, Parkin ubiquitin ligase activity has been shown to halt mitochondria motility by facilitating the degradation of Miro, a key adapter protein required to link mitochondria to kinesin motors (Wang et al., 2011). The observed increase in connectivity of cell body mitochondria and the lower levels of axonal mitochondria could be explained by a lack of Parkin-mediated degradation of mitofusins and Miro in the cell body, respectively.

Increased refinement of PD model systems beyond in vitro cultures was also recently achieved by Pickrell et al. (2015) in mice. In this study, researchers used a previously established model for accelerated aging in mice, a homozygous deficiency in the proofreading ability of the mitochondrial DNA polymerase $\gamma$, to examine how the largest risk factor for $\mathrm{PD}$, aging, is exacerbated by Parkin knock-out (KO). These prematurely aging mice, called $\mathrm{Mu}$ tator mice, were crossed with Parkin $\mathrm{KO}$ mice; their offspring (Mutator Parkin KO mice) displayed many of the characteristic PD pathologies, such as loss of dopaminergic neurons, lower striatal dopamine content, and impaired motor function (Pickrell et al., 2015, their Fig. 1). Although the mouse model used in this study may be limited in its malleability and long growth times in a way Drosophila is not, it does provide a powerful mammalian context for neuronal systems in vivo. While mitochondrial dynamics have not been examined in these mice, future studies to assess mitophagy and mitochondrial dynamics and expand on the in vivo neuronal work by Sung et al. (2016) could be done by crossing Mutator Parkin KO mice with mice expressing genetic markers of mitophagy, such as mito-QC (McWilliams et al., 2016) and mt-Keima (Sun et al., 2015) mice. Because PD pathology is selective to substantia nigra pars compacta neurons, levels of mitophagy between these neurons and other neurons should be compared.

$\mathrm{PD}$ is a complex disease, with the PINK1/Parkin pathway a prominent factor in disease pathology. Although in vitro studies of this pathway have led to important insights into protein function and activation, more studies benefiting from the varied advantages of different organismal neuronal models in vivo are necessary to understand the role of this pathway in PD pathogenesis.

\section{References}

Ashrafi G, Schlehe JS, LaVoie MJ, Schwarz TL (2014) Mitophagy of damaged mitochondria occurs locally in distal neuronal axons and requires PINK1 and Parkin. J Cell Biol 206:655670. CrossRef Medline

Bingol B, Tea JS, Phu L, Reichelt M, Bakalarski CE, Song Q, Foreman O, Kirkpatrick DS, Sheng M (2014) The mitochondrial deubiquitinase USP30 opposes Parkinmediated mitophagy. Nature 510:370-375. CrossRef Medline

Chen D, Gao F, Li B, Wang H, Xu Y, Zhu C, Wang G (2010) Parkin mono-ubiquitinates Bcl-2 and regulates autophagy. J Biol Chem 285: 38214-38223. CrossRef Medline

Davis AF, Clayton DA (1996) In situ localization of mitochondrial DNA replication in intact mammalian cells. J Cell Biol 135:883-893. CrossRef Medline

Deng H, Dodson MW, Huang H, Guo M (2008) 
The Parkinson's disease genes pink1 and Parkin promote mitochondrial fission and/or inhibit fusion in Drosophila. Proc Natl Acad Sci U S A 105:14503-14508. CrossRef Medline

Devireddy S, Liu A, Lampe T, Hollenbeck PJ (2015) The organization of mitochondrial quality control and life cycle in the nervous system in vivo in the absence of PINK1. J Neurosci 35:9391-9401. CrossRef Medline

Ghosh D, Walton JL, Roepe PD, Sinai AP (2012) Autophagy is a cell death mechanism in Toxoplasma gondii. Cell Microbiol 14:589-607. CrossRef Medline

Gomes LC, Di Benedetto G, Scorrano L (2011) During autophagy mitochondria elongate, are spared from degradation and sustain cell viability. Nat Cell Biol 13:589-598. CrossRef Medline

Kitada T, Asakawa S, Hattori N, Matsumine H, Yamamura Y, Minoshima S, Yokochi M, Mizuno Y, Shimizu N (1998) Mutations in the Parkin gene cause autosomal recessive juvenile parkinsonism. Nature 392:605-608. CrossRef Medline

Kujoth GC, Hiona A, Pugh TD, Someya S, Panzer K, Wohlgemuth SE, Hofer T, Seo AY, Sullivan R, Jobling WA, Morrow JD, Van Remmen H, Sedivy JM, Yamasoba T, Tanokura M, Weindruch R, Leeuwenburgh C, Prolla TA (2005) Mitochondrial DNA mutations, oxidative stress, and apoptosis in mammalian aging. Science 309:481-484. CrossRef Medline

Liu L, Feng D, Chen G, Chen M, Zheng Q, Song P, Ma Q, Zhu C, Wang R, Qi W, Huang L, Xue P, Li B, Wang X, Jin H, Wang J, Yang F, Liu P, Zhu Y, Sui S, et al. (2012a) Mitochondrial outer-membrane protein FUNDC1 mediates hypoxia-induced mitophagy in mammalian cells. Nat Cell Biol 14:177-185. CrossRef Medline

Liu S, Sawada T, Lee S, Yu W, Silverio G, Alapatt P, Millan I, Shen A, Saxton W, Kanao T, Takahashi R, Hattori N, Imai Y, Lu B (2012b) Parkinson's disease-associated kinase PINK1 regulates Miro protein level and axonal transport of mitochondria. PLoS Genet 8:e1002537. CrossRef Medline
McWilliams TG, Prescott AR, Allen GF, Tamjar J, Munson MJ, Thomson C, Muqit MM, Ganley IG (2016) mito-QC illuminates mitophagy and mitochondrial architecture in vivo. J Cell Biol 214:333-345. CrossRef Medline

Nguyen TN, Padman BS, Lazarou M (2016) Deciphering the molecular signals of PINK1/ Parkin mitophagy. Trends Cell Biol 26:733744. CrossRef Medline

Parkinson J (2002) An essay on the shaking palsy. 1817. J Neuropsychiatry Clin Neurosci 14:223-236; discussion 222. Medline

Pickrell AM, Youle RJ (2015) The roles of PINK1, Parkin, and mitochondrial fidelity in Parkinson's disease. Neuron 85:257-273. CrossRef Medline

Pickrell AM, Huang CH, Kennedy SR, Ordureau A, Sideris DP, Hoekstra JG, Harper JW, Youle RJ (2015) Endogenous Parkin preserves dopaminergic substantia nigral neurons following mitochondrial DNA mutagenic stress. Neuron 87:371-381. CrossRef Medline

Poole AC, Thomas RE, Yu S, Vincow ES, Pallanck L (2010) The mitochondrial fusion-promoting factor mitofusin is a substrate of the PINK1/ Parkin pathway. PLoS One 5:e10054. CrossRef Medline

Rambold AS, Kostelecky B, Elia N, LippincottSchwartz J (2011) Tubular network formation protects mitochondria from autophagosomal degradation during nutrient starvation. Proc Natl Acad Sci U S A 108:10190-10195. CrossRef Medline

Saxton WM, Hollenbeck PJ (2012) The axonal transport of mitochondria. J Cell Sci 125: 2095-2104. CrossRef Medline

Sun N, Yun J, Liu J, Malide D, Liu C, Rovira II, Holmström KM, Fergusson MM, Yoo YH, Combs CA, Finkel T (2015) Measuring in vivo mitophagy. Mol Cell 60:685-696. CrossRef Medline

Sung H, Tandarich LC, Nguyen K, Hollenbeck PJ (2016) Compartmentalized regulation of Parkin-mediated mitochondrial quality control in the Drosophila nervous system in vivo. J Neurosci 36:7375-7391. CrossRef Medline Tanaka A, Cleland MM, Xu S, Narendra DP, Suen
DF, Karbowski M, Youle RJ (2010) Proteasome and p97 mediate mitophagy and degradation of mitofusins induced by Parkin. J Cell Biol 191:1367-1380. CrossRef Medline

Trifunovic A, Wredenberg A, Falkenberg M, Spelbrink JN, Rovio AT, Bruder CE, Bohlooly YM, Gidlöf S, Oldfors A, Wibom R, Törnell J, Jacobs HT, Larsson NG (2004) Premature ageing in mice expressing defective mitochondrial DNA polymerase. Nature 429:417-423. CrossRef Medline

Valente EM, Abou-Sleiman PM, Caputo V, Muqit MM, Harvey K, Gispert S, Ali Z, Del Turco D, Bentivoglio AR, Healy DG, Albanese A, Nussbaum R, González-Maldonado R, Deller T, Salvi S, Cortelli P, Gilks WP, Latchman DS, Harvey RJ, Dallapiccola B, et al. (2004) Hereditary early-onset Parkinson's disease caused by mutations in PINK1. Science 304:11581160. CrossRef Medline

van der Bliek AM, Shen Q, Kawajiri S (2013) Mechanisms of mitochondrial fission and fusion. Cold Spring Harbor Perspect Biol 5:a011072. CrossRef Medline

Vermulst M, Wanagat J, Kujoth GC, Bielas JH, Rabinovitch PS, Prolla TA, Loeb LA (2008) DNA deletions and clonal mutations drive premature aging in mitochondrial mutator mice. Nat Genet 40:392-394. CrossRef Medline

Wang K, Klionsky DJ (2011) Mitochondria removal by autophagy. Autophagy 7:297-300. CrossRef Medline

Wang X, Winter D, Ashrafi G, Schlehe J, Wong YL, Selkoe D, Rice S, Steen J, LaVoie MJ, Schwarz TL (2011) PINK1 and Parkin target Miro for phosphorylation and degradation to arrest mitochondrial motility. Cell 147:893906. CrossRef Medline

Youle RJ, van der Bliek AM (2012) Mitochondrial fission, fusion, and stress. Science 337: 1062-1065. CrossRef Medline

Ziviani E, Tao RN, Whitworth AJ (2010) Drosophila Parkin requires PINK1 for mitochondrial translocation and ubiquitinates mitofusin. Proc Natl Acad Sci U S A 107: 5018-5023. CrossRef Medline 